\title{
The role of B-mode ultrasonography in the musculoskeletal anatomical evaluation of the cervical region of the dog spine ${ }^{1}$
}

\author{
Cibely G. Sarto ${ }^{2 *}$, Maria Cristina F.N.S. Hage ${ }^{3}$, Luciana D. Guimarães ${ }^{4}$, Robson F. \\ Giglio $^{5}$, Andréa P.B. Borges ${ }^{4}$ and Luiz C. Vulcano ${ }^{2}$
}

\begin{abstract}
Sarto C.G., Hage M.C.F.N.S., Guimarães L.D., Giglio R.F., Borges A.P.B. \& Vulcano L.C. 2014. The role of B-mode ultrasonography in the musculoskeletal anatomical evaluation of the cervical region of the dog spine. Pesquisa Veterinária Brasileira 34(1):91-97. Departamento de Veterinária, Centro de Ciências Biológicas e da Saúde, Universidade Federal de Viçosa, Avenida P.H. Rolfs s/n, Viçosa, MG 36570-000, Brazil. E-mail: cibegs@gmail.com

This study characterized the normal musculoskeletal anatomy of the cervical segment of the spine of dogs by means of B-mode ultrasonography. The objective was to establish the role of B-mode ultrasonography for the anatomical evaluation of the cervical spine segment in dogs, by comparing the ultrasonographic findings with images by computed tomography and magnetic resonance imaging. The ultrasound examination, in transverse and median sagittal sections, allowed to identify a part of the epaxial cervical musculature, the bone surface of the cervical vertebrae and parts of the spinal cord through restricted areas with natural acoustic windows, such as between the atlanto-occipital joint, axis and atlas, and axis and the third cervical vertebra. The images, on transverse and sagittal planes, by lowfield magnetic resonance imaging, were superior for the anatomical identification of the structures, due to higher contrast between the different tissues in this modality. Computed tomography showed superiority for bone detailing when compared with ultrasonography. As for magnetic resonance imaging, in addition to the muscles and cervical vertebrae, it is possible to identify the cerebrospinal fluid and differentiate between the nucleus pulposus and annulus fibrosus of the intervertebral discs. Although not the scope of this study, with knowledge of the ultrasonographic anatomy of this region, it is believed that some lesions can be identified, yet in a limited manner, when compared with the information obtained mainly with magnetic resonance imaging. The ultrasound examination presented lower morphology diagnostic value compared with the other modalities.
\end{abstract}

INDEX TERMS: Musculoskeletal ultrasound, cervical segment, dogs.

RESUMO.- [0 papel da ultrassonografia modo B na avaliação anatômica musculoesquelética do segmento cervical da coluna vertebral de cães.] Este estudo carac-

\footnotetext{
${ }^{1}$ Received on October 28, 2013.

Accepted for publication on January 14, 2014.

${ }^{2}$ Departamento de Reprodução Animal e Radiologia Veterinária, Faculdade de Medicina Veterinária e Zootecnia (FMVZ), Universidade Estadual Paulista (Unesp), Campus de Botucatu, Distrito de Rubião Júnior s/n, Botucatu, SP 18618-000, Brazil. *Corresponding author: cibegs@gmail.com

${ }^{3}$ Departamento de Medicina Veterinária, Faculdade de Zootecnia e Engenharia de Alimentos (FZEA), Universidade de São Paulo (USP), Av. Duque de Caxias Norte, 225, Campus da USP, Pirassununga, SP 13635-900, Brazil.

${ }^{4}$ Departamento de Veterinária (DVT), Centro de Ciências Biológicas e da Saúde (CCB), Universidade Federal de Viçosa (UFV), Avenida P.H. Rolfs s/n, Viçosa, MG 36570-000, Brazil.

${ }^{5}$ College of Veterinary Medicine, University of Florida, Small Animal Clinical Sciences, P.O. Box 100126, 2015 SW 16th Ave, Gainesville, FL 32610, USA.
}

terizou a anatomia musculoesquelética normal do segmento cervical da coluna vertebral de cães por meio da ultrassonografia modo B. O objetivo do trabalho foi estabelecer o papel da ultrassonografia modo B na avaliação anatômica do segmento cervical de cães, comparando os achados ultrassonográficos com imagens por tomografia computadorizada e ressonância magnética. 0 exame ultrassonográfico, em cortes transversais e sagitais mediano, permitiu a identificação de parte da musculatura epaxial do pescoço, superfície óssea das vértebras cervicais e medula espinhal em áreas restritas com janelas acústicas naturais, como entre a articulação atlantoccipital, áxis e atlas, e áxis e terceira vértebra cervical. As imagens, em planos transversais e sagitais, por ressonância magnética de baixo campo foram superiores na identificação anatômica das estruturas, de- 
vido ao maior contraste entre os diferentes tecidos nessa modalidade. A tomografia computadorizada se mostrou superior no detalhamento ósseo da região quando comparada ao exame ultrassonográfico. Já a ressonância magnética, além dos músculos e vértebras cervicais, permitiu a identificação do líquido cefalorraquidiano, e diferenciar núcleo pulposo e anel fibroso dos discos intervertebrais. Embora não seja objetivo direto deste estudo, com o conhecimento da anatomia ultrassonográfica dessa região, acredita-se que algumas lesões possam ser identificadas, contudo de maneira restrita, quando comparadas as informações obtidas, principalmente na imagem por ressonância magnética. 0 exame ultrassonográfico apresentou valor morfológico inferior.

TERMOS DE INDEXAÇÃO: Ultrassonografia musculoesquelética, segmento cervical, caninos.

\section{INTRODUCTION}

The neck region can be affected by different conditions that involve soft and osseous tissues, as by infectious (Holloway et al. 2009), neoplastic (Kim et al. 2005, Forterre et al. 2006, Bagley 2010) and congenital (Santos 2008, Cerda-Gonzalez \& Dewey 2010) diseases.

Among one of the most frequent diseases observed in the cervical-region is the degenerative disc disease, which, in spite of great knowledge acquired in the last 60 years, is still a common and challenging condition. In those, disc extrusion is the most common cause of neurological dysfunction in dogs (Brisson 2010). The cervical segment of the spinal cord is one of the most common sites of their occurrence, especially between the axis and the third and fourth cervical vertebrae (Widmer \& Thrall 2007).

For many years, myelography was the main diagnostic imaging modality used for the diagnosis of discopathies among animals and is still adequate for this purpose. Nowadays, the decision for the use of myelography in dogs with suspected degenerative disc disease is usually based on the lack of availability of computed tomography or magnetic resonance imaging (Robertson \& Thrall 2011).

The lower cost and broader availability of ultrasound examination of the musculoskeletal systems turn to be an attractive alternative in relation to the more expensive imaging methods, such as magnetic resonance imaging (Jacobson \& Van Holsbeeck 1998). Moreover, with ultrasonography it is possible to perform assessment of the structures in movement, by which one can obtain additional information (Berg et al. 2003). The ultrasound examination has potential value regarding the muscular and skeletal systems in small animals (Kramer et al. 1997), and the biggest challenge is the identification of an appropriate acoustic window. The manipulation of the articulation during the scanning process can help the examiner to identify the appropriate acoustic windows, providing information of the joint dynamics (Samii \& Long 2005).

Although computed tomography (CT) is a modality that uses ionizing radiation similar to the radiographic examination, CT is a superior modality of diagnostic imaging, because the transverse images obtained have more conspi- cuity when compared with two-dimensional radiographic projections (Gavin 2009), due to the better contrast resolution between the tissues and absence of superimposition (Ohlerth \& Scharf 2007), allowing better spatial resolution, resulting to be more adequate for bone imaging (Costa \& Samii 2010).

The examination through CT is enhanced by the use of contrast in the subarachnoid space, combining the benefits of CT and myelography. However, the disadvantages and side effects observed on the myelographic exam could also appear in the CT contrast exam, such as difficulty of administration of contrast, damages on the medulla, seizures, among other adverse effects (Robertson \& Thrall 2011).

On the other hand, magnetic resonance imaging (MRI) revolutionized neuroimaging and, if available, is a modality of diagnostic imaging adequate for most of the neurological patients. In this modality, there is no need for administration of a subarachnoid contrast medium and it provides relatively complete anatomic assess of the spinal cord and the vertebrae (Robertson \& Thrall 2011).

\section{MATERIALS AND METHODS}

A descriptive musculoskeletal ultrasonographic study of the cervical segment of the normal spine of 4 clinically normal mixed breed dogs ( 2 males and 2 females), weighing 10 to $15 \mathrm{~kg}$, from the kennel of the Departamento de Veterinária, Universidade Federal de Viçosa (UFV), was conducted. The images obtained were correlated with the macroscopic anatomy and with images by computed tomography and magnetic resonance imaging obtained from other dogs with similar weight. The standards of conduct for the use of animals in Ensino, Pesquisa e Extensão, from the Departamento de Veterinária (DVT/UFV) were followed rigorously. The project was certified by the Comissão de Ética para Uso de Animais da Universidade Federal de Viçosa (CEUA/UFV) (Animal Ethics Committee).

These animals had been previously radiographed for evaluation of the cervical segment of the spine and adjacent soft tissues. The radiographic machine used was an Omega 200T of $200 \mathrm{~mA}$ and $110 \mathrm{kV}$, with rotating anode X-Ray tube equipped with gridded table. The radiographic films were placed on metallic chassis with intensifying screens. Processing and fixation were done manually. The technique was based on the method that relates kilovoltage $(\mathrm{kV})$ and milliamperage $(\mathrm{mA})$, according to the thickness of the cervical segment. The laterolateral and ventrodorsal projections of the cervical segment were obtained from each animal.

For the ultrasound examination, the equipment SonoSite $\AA$ 180PLUS ${ }^{\mathrm{TM}}$ (version 1.99), equipped with two transducers - an electronic (C11) micro-convex ultrasound probe of 4.0 to $7.0 \mathrm{MHz}$ and a linear (L38) one from 5.0 to $10.0 \mathrm{MHz}$ - was utilized. Region hair clipping was performed before the application of ultrasound gel. The acquisition of images was done in B-mode on the median sagittal and transverse planes at level of the atlas, axis, fourth and seventh cervical vertebrae. Amplitude Doppler ultrasound was also used for identification of the vascular structure.

The CT images utilized in this research were obtained from a 8-year-old male poodle, through the equipment of the brand Shimadzu, model SCT-7800 TC, helical single-slice. The technique utilized was $120 \mathrm{kV}$ and $150 \mathrm{~mA}$, with 1 -second acquisition time, 1 -mm cut thickness, without the use of contrast, from the atlanto-occipital joint to the seventh cervical vertebra. On the computed tomography images, soft tissue and bone windows were evalua- 
ted according to Tidwell (2007). The examination was performed at the Laboratório de Tomografia Computadorizada (Computed Tomography Laboratory) at Faculdade de Medicina Veterinária e Zootecnia, Unesp, Botucatu Campus.

The MRI images used in this research were obtained from a recently euthanized corpse of a 17-kg female mixed breed dog by the equipment from the brand Esaote model Vet MR Grande, of 0.25 Tesla, using spine coil number 13. Imaging planes obtained were transverse and sagittal. Images sequences obtained were T1-weighted Spin Echo (SE); T2-weighted Fast Spin Echo (FSE); proton density (PD) weighted Turbo Multi Echo (TME); 3D Hyce and Fast Short Tau Inversion Recovery (STIR). The Fast STIR sequence was only performed on the sagittal plane.

The animals used for the anatomical slice cuts were gathered from the classes of practical of surgery or surgical technique (without compromising of the cervical segment). After the class, they were euthanized, according to the regulation from the Animal Ethics Committee of the Universidade Federal de Viçosa. Corpses were frozen, and then with a band saw, cuts were done on the transverse plane, at the necropsy room of the Departamento de Veterinária, Universidade Federal de Viçosa.

Macrophotographic images of the anatomical slice were taken with a digital câmera Sony Cybershot Super Steady Shot DSC-H2, and organized with the software CorelDRAW ${ }^{\circledR}$ and Microsoft ${ }^{\circledR}$ PowerPoint 2007.

Afterwards, images of the anatomical parts were compared with the images from the ultrasound, CT and MRI images of the cervical region, with the aid of anatomy (Schaller 1999, Done et al. 2002, König \& Liebich 2002, Dyce et al. 2010) and diagnostic imaging books (Assheuer \& Sager 1997, Bagley et al. 2009).

\section{RESULTS}

The cranial cervical vertebrae such as the atlas (Fig.1), the axis (Fig.2) and the fourth cervical vertebra (Fig.3) were more identified on the ultrasonographic examination, both on the transverse plane and median sagittal. The identification of the seventh cervical vertebra (Fig.4) on transverse and sagittal plans was more difficult.

The linear transducer (L38) with broadband of 5.0 through $10.0 \mathrm{MHz}$ presented better definition of the cervical structures compared with the micro-convex (C11) transducer of broadband of 4.0 to $7.0 \mathrm{MHz}$. Notwithstanding, a precise demarcation of the muscles was not possible
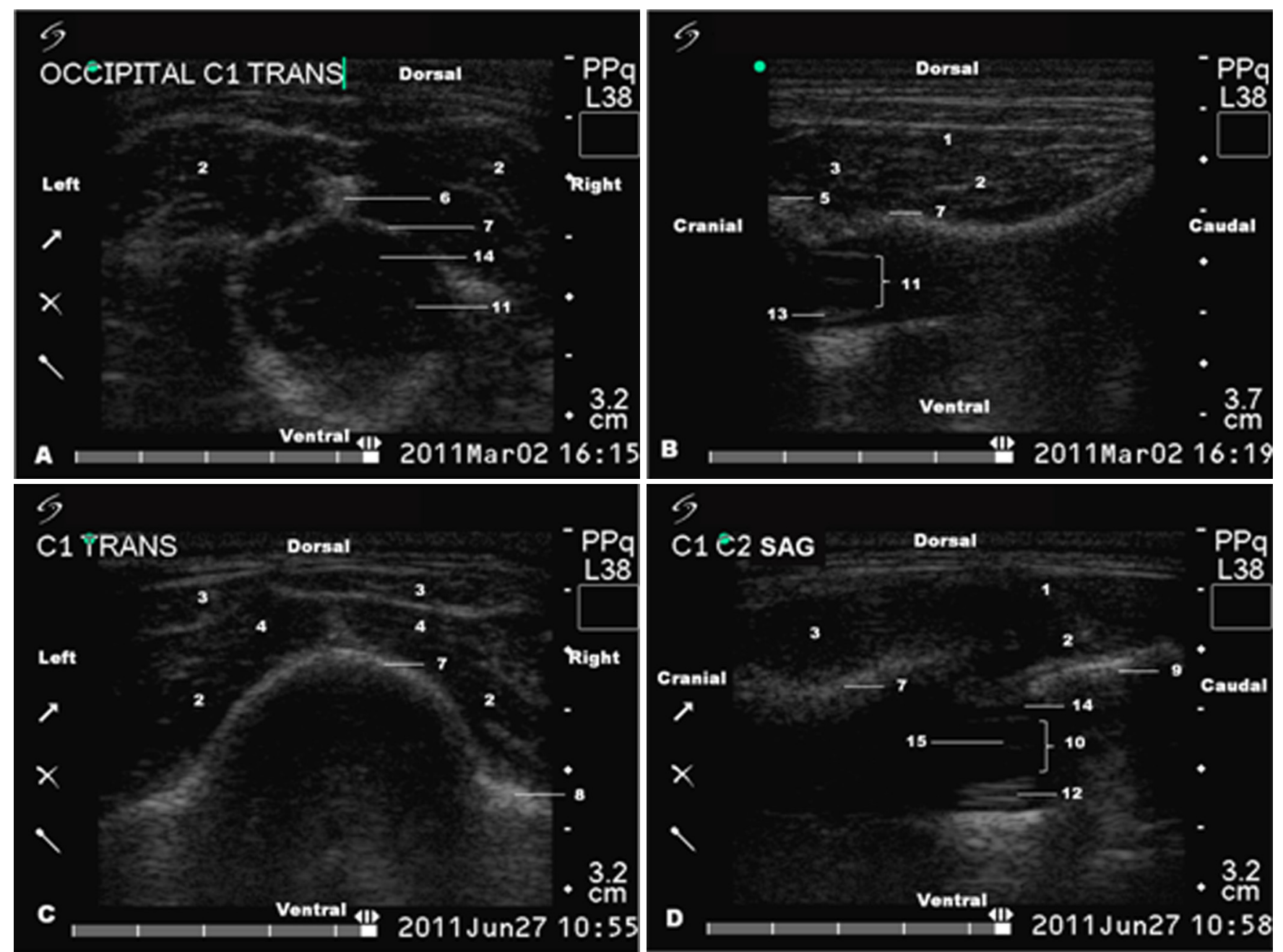

Fig.1. Ultrasonographic image (A) of the atlanto-occipital articulation, (B) atlas region in transverse, and (C,D) sagittal planes. Structures identified: (1) Biventer cervicis muscle, (2) Obliquus capitis ventralis muscle, (3) Obliquus capitis dorsalis muscle, (4) Rectus capitis dorsalis major, (5) Occipital protuberance, (6) Tubercle of the neck, (7) Anterior arch of the atlas, (8) Transverse process of the atlas, (9) Spinous process of the axis, (10) Spinal cord, (11) Bulb, (12) Ventral internal vertebral plexus, (13) Basilar artery, (14) Subarachnoid space, (15) Central canal of the spinal cord. 


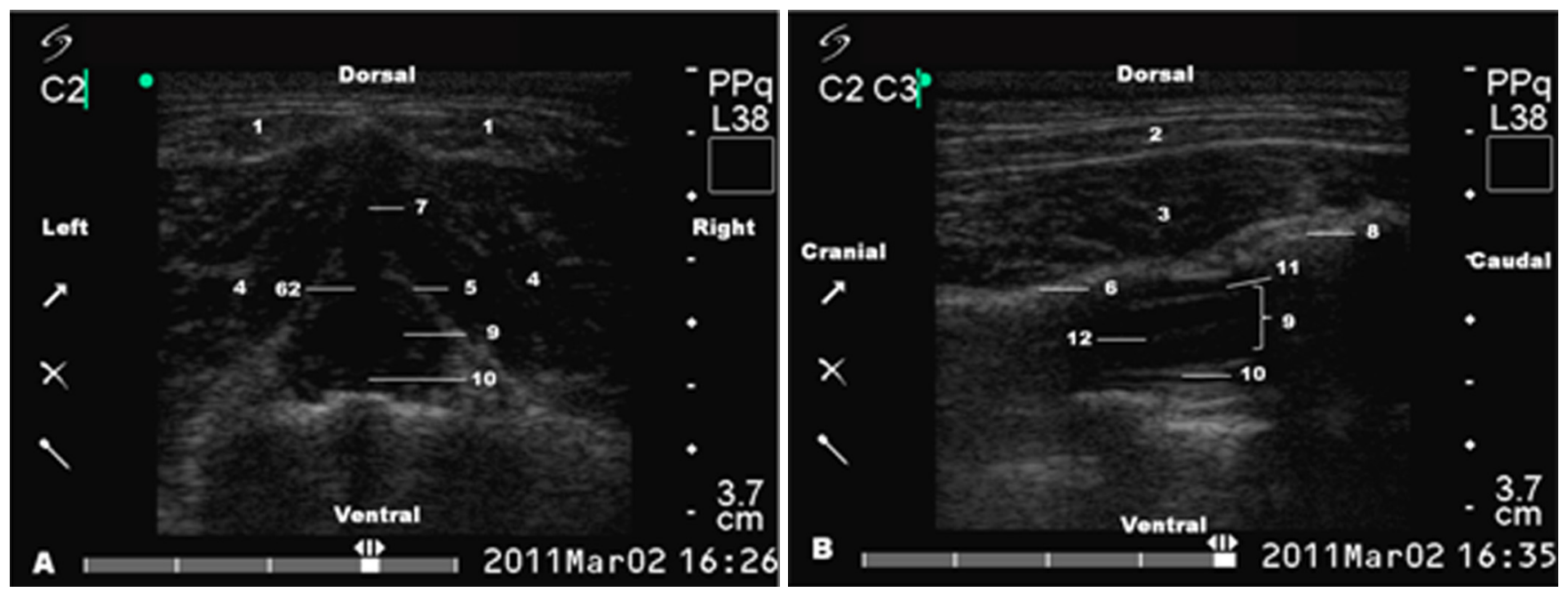

Fig.2. Ultrasonographic image (A) of the axis on transverse plane, and (B) between the axis and third cervical vertebra on sagittal plane. Structures identified: (1) Biventer cervicis muscle, (2) Cervical spinal muscle, (3) Multifidi muscles, (4) Obliquus capitis ventralis muscle, (5) Anterior arch of the atlas, (6) Anterior arch of the axis, (7) Spinous process of the axis, (8) Dorsal arch of third cervical vertebra, (9) Spinal cord, (10) Ventral internal vertebral plexus, (11) Subarachnoid space, (12) Central canal of the spinal cord.

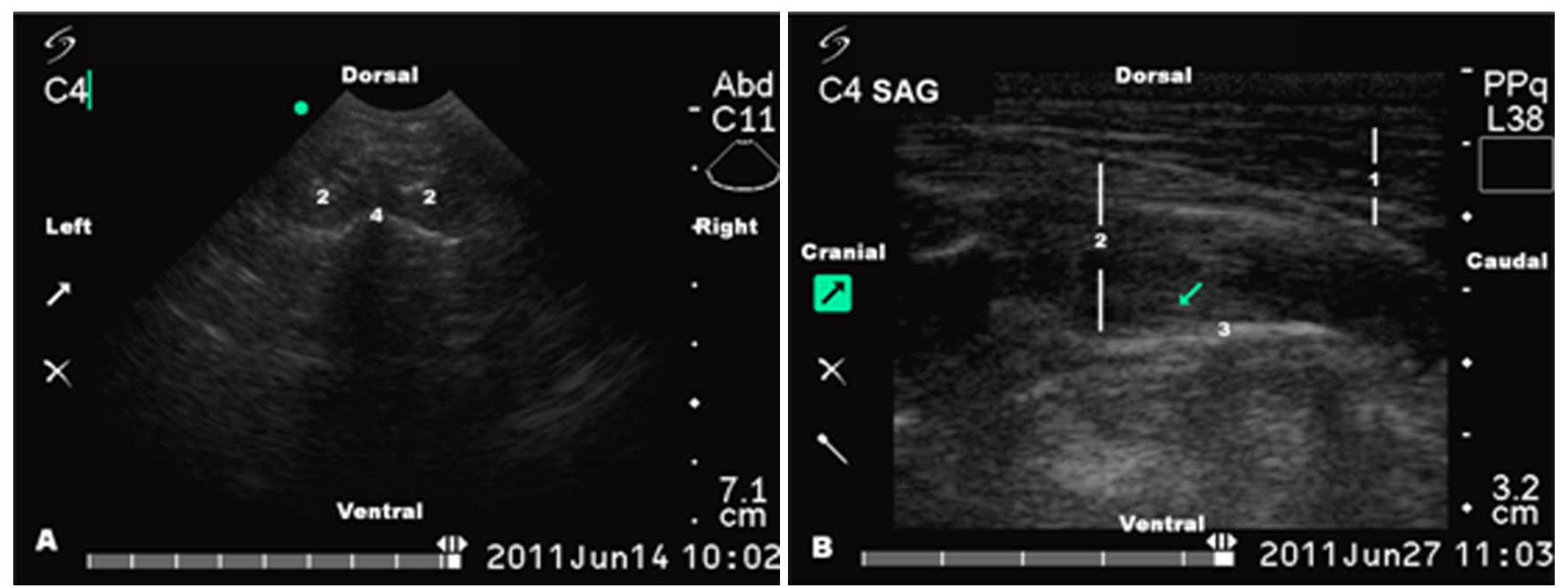

Fig.3. Ultrasonographic image (A) of the fourth cervical vertebra on transverse, and (B) sagittal (arrow) planes. Structures identified: (1) Cervical spinal muscle, (2) Multifidi muscles, (3) Fourth cervical vertebra dorsal arch, (4) Spinous process of fourth cervical vertebra.

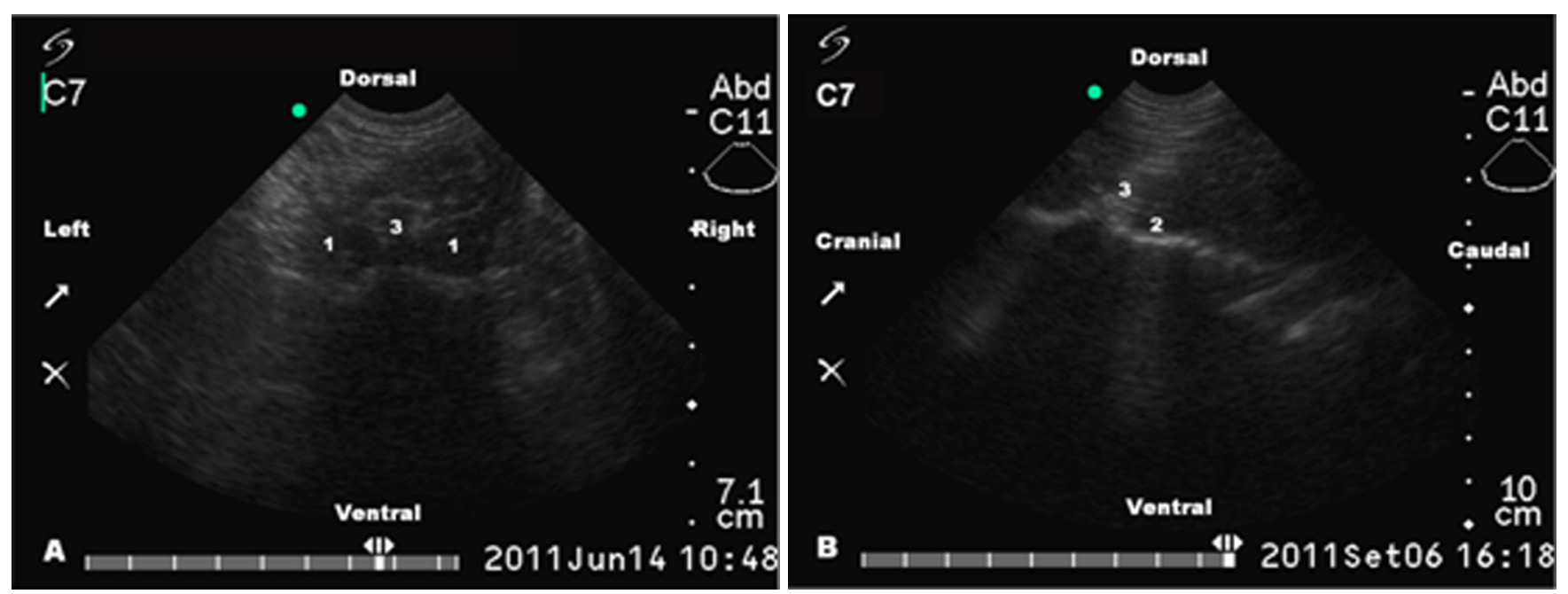

Fig.4. Ultrasographic image (A) of the seventh cervical vertebra on transverse and (B) sagittal planes. Structures identified: (1) Multifidi muscles, (2) Seventh cervical vertebra dorsal arch, (3) Spinous process of seventh cervical vertebra. 
with either transducers. With the linear one, it was possible to identify the biventer cervicis; cervical spinal muscle; obliquus capitis ventralis and dorsalis muscles; rectus capitis dorsalis major; and multifidi muscles. With the micro-convex transducer, on the other hand, only the multifidi muscles were delimited.

As for the vascularization at the ultrasonographic examination, the identification of the basilar artery and ventral internal vertebral plexus was possible. The basilar artery (Fig.1B) was identified only on the sagittal plane, at the level of the atlanto-occipital joint. The ventral internal vertebral plexus was visualized on the sagittal sectioning between the atlas and the axis (Fig.1D), and the axis and the third cervical vertebra (Fig.2B); and on the transverse plane of the axis (Fig. A). The equipment utilized presents the function Amplitude Doppler; the team tried to use this software, but the machine was not sensitive to detect the flow of these small caliber vessels. Thus, the identification of both vessels was only possible due to their pulsation.

The bulb was visualized on the ultrasonographic images on tranverse (Fig.1A) and sagittal (Fig.1B) planes at the level of atlanto-occipital joint, and, the spinal cord, between the atlas and the axis (Fig.1D), and the axis and the third cervical vertebra (Fig.2B). On the transverse plane, it was also possible to visualize the spinal cord on the region of the axis (Fig.2A). Additionally, it was possible to identify the central canal (Fig.1D and 2B).

One difficulty found with the linear transducer was regard the coupling of the body surface on the contact surface of the transducer, especially on the sagittal plane of the atlanto-occipital joint, with a need for flexing the head of the dog evaluated, so the surface of the transducer was completely in contact with the skin of the animal.

At the CT examination, images were obtained only on the transverse plane, since the equipment utilized did not present computational features for the reconstruction of the images on other planes.The CT exam did not differentiated with ood accuracy the soft tissue parts; however, it enabled better osseous detailing, so that it was possible to identify on the vertebrae: transverse process of the atlas, axis dens, crista ventralis of the axis, anterior arch, spinal canal, transverse foramen, vertebral body, spinal and transverse processes. Concerning the soft tissues, it was possible to identify, in the region of the seventh cervical vertebra, cervical spinal muscles, multifidi muscle and the nuchal ligament.

In the animal in which CT was performed, there was no administration of contrast. Therefore, it was not possible to compare the spinal cord delineated by contrast at the tomography examination with the other modalities of imaging assessed.

At the examination by magnetic resonance imaging (MRI), it was possible to identify cerebrospinal fluid (CSF), cortical and medullary osseous, nucleous pulposus and annulus fibrosus of the invertebral disc.

In this study, the images by MRI were obtained using a cadaver, which enabled a longer time for acquisition of images. Besides, because this is a study of anatomical description, the group chose to utilize five pulse sequences, since they were already available on the equipment, and two imaging planes (transversal and sagittal), aiming to identify the most anatomical structures.

Out of the five sequences utilized, 3D Hyce was the one that showed best resolution of images; in ascending order of signal, the bones and other mineralized structures, soft tissues and CSF were visualized.

On the T1-weighted Spin Echo image sequence, it was also possible to identify the musculature, based on the previous anatomic knowledge. Yet on the T2-weighed Fast Spin Echo sequence, the water contrast superior to the SE sequence allowed the identification of the nucleus of the invertebral disc and CSF. However, in relation to the resolution, T2-weighed images for the identification of the muscle structures presented higher degree of difficulty.

The images from the PD-weighted Turbo Multi Echo sequence enabled identification of great part of the structures visualized on $\mathrm{T} 1$; however, the resolution was not so favorable when compared with the T1 and 3D Hyce-weighted SE sequences.

On the FAST STIR sequence, however, it was possible to clearly identify the CSF, for the epidural fat, in addition to the invertebral discs, bulb and spinal cord. Nevertheless, in this sequence, the musculature visualized with low signal presented greater difficulty of identification.

\section{DISCUSSION}

In order to produce a reliable interpretation during the ultrasound, deep knowledge of the transverse and sagittal anatomy is necessary (Berg et al. 2003). On this way, the utilization of anatomical parts frozen in transverse sections helped the identification of the anatomical structures on the ultrasound, tomography and low-field MR images.

For more complex structures, such as the axial skeleton, it is necessary to use a 5.0-MHz transducer (Samil \& Long 2005). However, even utilizing a 5.0-10.0 MHz broadband transducer, the obtainment of ideal images was hampered by the loss of definition of the image on deeper sites to attenuation of the sound beam, by the thickness of the epaxial muscles. A lower-frequency transducer (2.0 to $3.0 \mathrm{MHz}$ ) might have been better at the delimitation of these structures; however, it was not available.

The better definition observed by the linear transducer (C38) is explainable, since this kind of transducer utilized for the musculoskeletal evaluation, because of its high frequency, having better image resolution, although low penetrance in the tissue, is ideal for little superficial structures (Lew et al. 2007). Even with this characteristic, the clear delimitation of the muscles was not possible, once these structures present a heterogeneous appearance due to the hypoechoic muscle fibers, fat tissue and variation in the degree of hypoechoic collagen fibers (Beef 1998).

The spinal cord observed in the regions where there were natural acoustic windows were visualized as a hypoechoic structure outlined by two hypoechoic lines, which represented the pia mater (Etienne et al. 2010).

Transverse and sagittal plane with linear transducer at the joint atlantoccipital allowed measuring the distance between the skin and the subarachnoid space, which facili- 
tates the choice of needle to the contrast administration for myelography or myelotomography, as performed by Kim et al. (2008), which describe in a human study on cervical epidural block to estimate the length of the needle by ultrasonography provides a high accuracy and depth, reducing the possibility of complications.

For the examination by CT to obtain images in different planes other than transverse, the position of the animal would have to be changed; however, this implies a longer time of anesthesia and size of the gantry, fact described in a study that correlates anatomical parts with ultrasound and tomography images of the encephalon of dogs (Lorigados 2008).

The low capacity of CT to differentiate soft tissues (Assheuer \& Sager 1997) suggests that the examination could be complemented with the ultrasound images, since the biggest part of the ultrasound beam does not go beyond the osseous cortical, but can provide information as for the paravertebral muscles. This is because the ultrasound examination provided greater detailing of the musculature of the cervical segment of the spine of dogs, allowing the visualization of the muscle fibers (Kramer et al. 1997).

The 3D Hyce sequence is characterized by the quality of resolution, which allowed obtaining a good anatomical description, since the soft tissues showed hypointense in a uniform manner (Dennis 2011), and CSF with hyperintensity, gives myelographic effect (Westbrook 2002).

The T1-weighted SE pulse sequence is characterized by the excellent representation of anatomy, although with lower water contrast than the T2-weighted images (Dennis 2011); this hypointensity of the liquids at T1 is what makes them different from the sequences at T2 (Costa \& Samii 2010).

The PD-weighted Turbo Multi Echo sequence is described by some authors with great definition of structures (Hage et al. 2010). This may be related to the equipment utilized, because in the study mentioned, the equipment utilized was of 1.5 Tesla, contrasting with the 0.25 Tesla of the present study, which may have influenced the resolution of the images acquired.

The FAST STIR sequence, for being a technique of fat suppression T2-weighted (Gavin 2009), with an excellent contrast between the white and grey matter (Konar \& Lang 2011) is utilized particularly in equipments of low-field MR (Dennis 2011). The fat which is typically hyperintense, both at T1 and T2 weightings, will present low signal (Costa \& Samii 2005). Thus, the clear identification of the CSF is explained by the differentiation of the epidural fat (Costa \& Samii 2005).

\section{CONCLUSIONS}

The ultrasound examination of the cervical segment of the spine of dogs could be useful as a screening test, in patients that cannot be sedated or anesthetized for the radiographic examination, or in places where the computed tomography or magnetic resonance equipment are not available.

Few studies approach musculoskeletal aspects of the cervical segment, which presents perspectives for more re- search on ultrasound with high-resolution equipments, on different imaging planes.

It is expected that, with acquired knowledge of ultrasound anatomy of this region, some lesions can be identified; however, in a restricted way, if compared with the supplied information, especially at magnetic resonance imaging.

The results showed the feasibility of the technique enabling the study of animals affected with diseases in the cervical region.

Acknowledgements.- To Conselho Nacional de Desenvolvimento Científico e Tecnológico (CNPq) for the granting of a Master's scholarship. To Dr. Francisco Hato, director of "Cães e Gatos" Veterinary Hospital (Osasco, São Paulo) for his kindness in performing magnetic resonance imaging. To veterinarian Letícia Corrêa Santos for lending her dogs to perform practice ultrasound examinations.

\section{REFERENCES}

Assheuer J. \& Sager M. 1997. MRI and CT Atlas of the Dog. Blackwell Science, Oxford. 482p.

Bagley R.S. 2010. Spinal neoplasms in small animals. Vet. Clin. North Am., Small Anim. Pract. 40:915-927.

Bagley R.S., Gavin P.R. \& Holmes S.P. 2009. Diagnosis of spinal disease. p.123-226. In: Gavin P.R. \& Bagley R.S. (Eds), Practical Small Animal MRI. Wiley-Blackwell, Iowa.

Beef V.B. 1998. Musculoskeletal ultrasonography, p.39-186. In: Ibid. (Ed.), Equine Diagnostic Ultrasound. W.B. Saunders, Philadelphia.

Berg L.C., Nielsen J.V., Thoefner M.B. \& Thomsen P.D. 2003. Ultrasonography of the equine cervical region: a descriptive study in eight horses. Equine Vet. J. 35:647-655.

Brisson B.A. 2010. Intervertebral disc disease in dogs. Vet. Clin. North Am., Small Anim. Pract. 40:829-858.

Cerda-Gonzalez S. \& Dewey C.W. 2010. Congenital diseases of the craniocervical junction in the dog. Vet. Clin. North Am., Small Anim. Pract. 40:121-141.

Costa R.C. \& Samii V.F. 2010. Advanced imaging of the spine in small animals. Vet. Clin. North Am., Small Anim. Pract. 40:765-790.

Dennis R. 2011. Optimal magnetic resonance imaging of the spine. Vet. Radiol. Ultrasound 52:S72-S80.

Done S.H., Goodoy P.C., Evans S.A. \& Stickland N.C. 2002. Atlas Colorido de Anatomia Veterinária do Cão e do Gato. Vol.3. Manole, São Paulo. 614p.

Dyce K.M., Sack W.O. \& Wensing C.J.G. 2010. Tratado de Anatomia Veterinária. 4⿳亠丷a ed. Elsevier, Rio de Janeiro. 856p.

Etienne A.-L., Peeters D. \& Busoni V. 2010. Ultrasonographic percutaneous anatomy of the caudal lumbar region and ultrasound-guided lumbar puncture in the dog. Vet. Radiol. Ultrasound 51:527-532.

Forterre F., Kaiser S., Matiasek K. \& Brunnberg L. 2007. Adenocarcinoma metastasis of the intertransversarius cervicis muscle eliciting a right forelimb lameness in a dog. J. Vet. Med. A. 54:250-253.

Gavin P.R. 2009. Physics: comparative imaging, p.1-3. In: Gavin P.R. \& Bagley R.S. (Eds), Practical Small Animal MRI. Wiley-Blackwell, Iowa.

Hage M.C.F.N.S., Iwasaki M., Rabbani S.R., Kamikawa L., Cervantes H.J.R., Bombonato P.P., Sterman F.A. \& Otaduy M.C.G. 2010. Imagem por ressonância magnética na investigação da cabeça de cães. Pesq. Vet. Bras. 30:593-604.

Holloway A., Dennis R., McConnell F. \& Herrtage M. 2009. Magnetic resonance imaging features of paraspinal infection in the dog and cat. Vet. Radiol. Ultrasound 50:285-291.

Jacobson J.A. \& Van Holsbeeck M.T. 1998. Musculoskeletal ultrasonography. Orthop. Clin. North Am. 29:135-167.

Kim H.-J., Chang H.-S., Choi C.-B., Song Y.-S., Kim S.-M., Lee J.-S. \& Kim H.Y. 2005. Infiltrative lipoma in cervical bones in a dog. J. Vet. Med. Sci. 6:1043-1046. 
Konar M. \& Lang J. 2011. Pros and cons of low-field magnetic resonance imaging in veterinary practice. Vet. Radiol. Ultrasound 52:S5-S14.

König H.E. \& Liebich H.-G. 2002. Anatomia dos Animais Domésticos. Artmed, Porto Alegre. 397p.

Kramer M., Gerwing M., Hach V. \& Schimke E. 1997. Sonography of the musculoskeletal system in dogs and cats. Vet. Radiol. Ultrasound 38:139-149.

Lew H.L., Chen C.P.C., Wang T.-G. \& Chew K.T.L. 2007. Introduction to musculoskeletal diagnostic ultrasound: examination of the upper limb. Am. J. Phys. Med. Rehabil. 86:310-321.

Lorigados C.A.B. 2008. Utilização da ultra-sonografia modo B e da tomografia computadorizada no estudo do encéfalo de cães adultos. Tese de Doutorado em Clínica Cirúrgica Veterinária, Universidade de São Paulo, São Paulo, SP. 88p.

Ohlerth S. \& Scharf G. 2007. Computed tomography in small animals: Basic principles and state of the art applications. Vet J. 173:254-271.

Robertson I. \& Thrall D.E. 2011. Imaging dogs with suspected disc hernia- tion: pros and cons of myelography, computed tomography, and magnetic resonance. Vet. Radiol. Ultrasound 52:S81-S84.

Samii V.F. \& Long C.D. 2005. Sistema musculoesquelético, p.273-291. In: Mattoon J.S. \& Nyland T.G. (Eds), Ultra-Som Diagnóstico em Pequenos Animais. $2^{\mathrm{a}}$ ed. Roca, São Paulo.

Santos J.P.A. 2008. Ultra-sonografia muscular cervical e pélvica de cães da raça Golden Retriever portadores e afetados pela Distrofia Muscular e em, terapia celular. Dissertação de Mestrado em Anatomia dos Animais Domésticos e Silvestres, Universidade de São Paulo, São Paulo, SP. 144p.

Schaller 0. 1999. Nomenclatura Anatômica Veterinária Ilustrada. Manole, São Paulo. 614p.

Westbrook C. 2002. Sequências de pulso, p.10-19. In: Ibid. (Ed.), Manual de Técnicas de Ressonância Magnética. $2^{\underline{a}}$ ed. Guanabara Koogan, Rio de Janeiro.

Widmer W.R. \& Thrall D.E. 2007. Canine and feline intervertebral disc disease, myelography, and spinal cord disease, p.194-219. In: Thrall D.E. (Ed.), Textbook of Veterinary Diagnostic Radiology. $5^{\text {th }}$ ed. Saunders Elsevier, Saint Louis, Missouri. 